\title{
SYNTHESIS AND DIURETIC PROPERTIES OF $N$-ARYL- 6-HYDROXY-2-METHYL-4-OXO-2,4-DIHYDRO-1H-PYRROLO [3,2,1-ij]QUINOLINE-5-CARBOXAMIDES WITH ELECTRON- ACCEPTOR SUBSTITUENTS IN THE ANILIDE FRAGMENT
}

\author{
I.V.Ukrainets, M.Yu.Golik, O.L.Shemchuk, V.M.Kravchenko \\ National University of Pharmacy, \\ 53, Pushkinska str., Kharkiv, 61002, Ukraine. E-mail: uiv-2@mail.ru
}

Key words: anilides; 4-hydroxy-2-oxo-1,2-dihydroquinoline-3-carboxamides; pyrroloquinolines; amidation; hydrolysis; diuretic activity

In numerous studies of 4-hydroxy-2-oxo-1,2-dihydroquinoline-3-carboxamides it has been convincingly shown that amidation of quinoline-3-carboxylic acids esters with alkyl-, aryl- and hetarylamines is the best way to obtain these compounds. As a rule, syntheses proceed smoothly and efficiently under rather mild conditions. However, in those cases when for formation of amides the temperature of $120-150^{\circ} \mathrm{C}$ and above is applied, partial destruction of the ester fragment may occur and, as a result, it pollutes the target products with specific impurities - the corresponding 4-hydroxy-1,2dihydroquinolin-2-ones or their analogues. Application of ${ }^{1} H$ NMR spectroscopy allows to prove that the cause of ester fragments destruction, which sometimes can be observed when alkyl 4-hydroxy-2-oxo-1,2-dihydroquinoline-3-carboxylates react with amines under harsh conditions, is water presented in the reagents or in the solvents. It becomes clear from this study that at the temperature of $95^{\circ} \mathrm{C}$ and higher the sensitivity of 4-hydroxy-2-oxo-1,2-dihydroquinoline3-carboxylic acids esters in a solution or a melt to hydrolysis increases significantly. Simple methods to minimize this undesirable process have been proposed - if the synthesis of $\mathrm{N}$-substituted amides based on them requires such severe conditions, water should be removed from the reagents and solvents in order to avoid contamination of the final products with 4-hydroxy-1,2-dihydroquinolin-2-ones. The results of the diuretic properties study of new substituted anilides of 6-hydroxy-2-methyl-4-oxo-2,4-dihydro-1H-pyrrolo[3,2,1-ij]quinoline-5-carboxylic acid are discussed.

СИНТЕЗ ТА ДІУРЕТИЧНІ ВЛАСТИВОСТІ N-АРИЛ-6-ГДРОКСИ-2-МЕТИЛ-4-ОКСО-2,4-ДИГДРО-1Н-ПІРОЛО[3,2,1-іj] ХІНОЛІН-5-КАРБОКСАМІДІВ З ЕЛЕКТРОНО-АКЦЕПТОРНИМИ ЗАМІСНИКАМИ В АНІЛІДНОМУ ФРАГМЕНТІ І.В.Українець, М.Ю.Голік, О.Л.Шемчук, В.М.Кравченко

Ключові слова: аніліди; 4-гідрокси-2-оксо-1,2-дигідрохінолін-3-карбоксаміди; піролохіноліни; амідування; гідроліз; діуретична активність

У процесі численних досліджень, присвячених 4-гідрокси-2-оксо-1,2-дигідрохінолін-3-карбоксамідам, було переконливо показано, що кращим методом одержання таких сполук є амідування естерів хінолін-3-карбонових кислот алкіл-, арил- чи гетариламінами. Як правило, синтези проходять гладко та ефективно в досить м'яких умовах. Однак у тих випадках, коли для фрормування амідів потрібна температура $120-150^{\circ} \mathrm{C}$ i вище, можливе часткове розкладання естерного фрагменту і як результат забруднення цільових продуктів специфрічними домішками - відповідними 4-гідрокси-1,2-дигідрохінолін-2-онами або їх аналогами. За допомогою спектроскопії ЯМР ${ }^{1} \mathrm{H}$ доведено, що причиною деструкції естерних фррагментів, яка інколи спостерігається при взаємодії алкіл 4-гідрокси-2-оксо-1,2-дигідрохінолін-3-карбоксилатів з амінами в жорстких умовах, $\epsilon$ присутня в реагентах чи розчиннику вода. 3 проведеного дослідження видно, що при температурі $95^{\circ} \mathrm{C} i$ вище чутливість до гідролізу естерів 4-гідрокси-2-оксо-1,2-дигідрохінолін-3-карбонових кислот, які перебувають у розчині чи розплаві, сутmєво зростає. Запропоновані прості способи мінімізації цього небажаного процесу - якщо синтез на їх основі N-заміщених амідів потребує жорстких умов, то для запобігання забрудненню кіниевих продуктів 4-гідрокси-1,2-дигідрохінолін-2-онами необхідно видаляти воду з реагентів та розчинників. Обговорюються результати вивчення діуретичних властивостей нових заміщених анілідів 6-гідрокси-2-метил-4-оксо-2,4-дигідро-1Н-піроло[3,2,1-іј]хінолін-5-карбонової кислоти.

СИНТЕЗ И ДИУРЕТИЧЕСКИЕ СВОЙСТВА N-АРИЛ-6-ГИДРОКСИ-2-МЕТИЛ-4-ОКСО-2,4-ДИГИДРО-1Н-ПИРРОЛО[3,2,1-іј]ХИНОЛИН-5-КАРБОКСАМИДОВ С ЭЛЕКТРОНОАКЦЕПТОРНЫМИ ЗАМЕСТИТЕЛЯМИ В АНИЛИДНОМ ФРАГМЕНТЕ И.В.Украинец, Н.Ю.Голик, А.Л.Шемчук, В.Н.Кравченко

Ключевые слова: анилиды; 4-гидрокси-2-оксо-1,2-дигидрохинолин-3-карбоксамиды; пирролохинолины; амидирование; гидролиз; диуретическая активность

В процессе многочисленных исследований, посвященных 4-гидрокси-2-оксо-1,2-дигидрохинолин-3-карбоксамидам, было убедительно показано, что лучшим методом получения таких соединений является амидирование сложных эфриров хинолин-3-карбоновых кислот алкил-, арил- и гетариламинами. Как правило, синтезы проходят гладко и эффрективно в довольно мягких условиях. Однако в тех случаях, когда для фрормирования амидов требуется температура $120-150^{\circ} \mathrm{C}$ и выше, возможно частичное разрушение сложноэфрирного фррагмента и как результат загрязнение целевых продуктов специфрическими примесями - соответствующими 4-гидрокси-1,2-дигидрохинолин-2-онами или их аналогами. С помощью спектроскопии ЯМР ${ }^{1}$ Н доказано, что причиной деструкции сложноэфирных фррагментов, иногда наблюдающейся при взаимодействии алкил 4-гидрокси-2-оксо-1,2-дигидрохинолин-3-карбоксилатов с аминами в жестких условиях, является присутствующая в реагентах или растворителе вода. Из проведенного исследования следует, что при температуре $95^{\circ} \mathrm{C}$ и выше чувствительность к гидролизу находящихся в растворе или расплаве сложных эфиров 4-гидрокси-2-оксо-1,2-дигидрохинолин-3-карбоновых кислот существенно возрастает. Предложены простые способы минимизации этого нежелательного процесса - если синтез на их основе N-замещённых амидов требует столь жестких условий, то во избежание загрязнения конечных продуктов 4-гидрокси-1,2-дигидрохинолин-2-онами необходимо удалять воду из реагентов и растворителей. Обсуждаются результаты изучения диуретических свойств новых замещённых анилидов 6-гидрокси-2метил-4-оксо-2,4-дигидро-1Н-пирроло[3,2,1-іj]хинолин-5-карбоновой кислоты. 
In numerous studies of 4-hydroxy-2-oxo-1,2-dihydroquinoline-3-carboxamides it has been convincingly shown that amidation of quinoline-3-carboxylic acids esters with alkyl-, aryl- and hetarylamines is the best way to obtain these compounds [2-6]. As a rule, syntheses proceed smoothly and efficiently under rather mild conditions. However, in those cases when for formation of amides the temperature of $120-150^{\circ} \mathrm{C}$ and above is applied, partial destruction of the ester fragment may occur and, as a result, it pollutes the target products with specific impurities the corresponding 4-hydroxy-1,2-dihydroquinolin-2ones or their analogues [7-10]. This effect is the most significant for amines with low nucleophilicity, for example, anilines with electron-accepting substituents in the aromatic ring.

Simple experiments carried out directly in the ampoule of the NMR spectrometer were used to determine the cause of this undesirable reaction. At first, to solve the problem the ${ }^{1} \mathrm{H}$ NMR spectra of the substances most readily undergoing destruction, namely methyl esters of 4-hydroxy-2-oxo-1,2,5,6,7,8-hexahydro- [7] and 4-hydroxy-6,7-dimethoxy-2-oxo-1,2dihydro- [10] quinoline-3-carboxylic acids, as well as ethyl ester of 6-hydroxy-2-methyl-4-oxo-2,4-dihydro-1 $H$-pyrrolo[3,2,1-ij]quinoline-5-carboxylic acid [8] and its 2-methyl-substituted analogue 1 [9], were registered in DMSO- $\mathrm{d}_{6}$ at the room temperature. These data served as the initial control.

Then temperatures of the samples were increased, kept at the same range for a certain period of time, and a new ${ }^{1} \mathrm{H}$ NMR spectrum was registered. Afterwards the next measurement at higher temperature was performed. The experiment lasted until the evidence of the ester fragments destruction appeared in the ${ }^{1} \mathrm{H}$ NMR spectrum.

The behaviour of all esters tested is similar - they are quite stable in DMSO- $\mathrm{d}_{6}$ at $80^{\circ} \mathrm{C}$. However, at $95^{\circ} \mathrm{C}$ during 5-25 minutes of heating the first signs of the ester groups decomposition are detected: along with the initial esters, methyl or ethyl alcohols and related quinolinecarboxylic acids type 2 are registered in the reaction mixture. It is a well-known fact [11] that they are extremely unstable and rapidly decarboxylize to 4-hydroxy-1,2-dihydroquinolin-2-ones in solution as evidenced by instant appearance of $\mathrm{H}-3$ protons characteristic singlets in the ${ }^{1} \mathrm{H}$ NMR spectra at 5.40-5.80 ppm. With the further increase of the temperature the process of esters decomposition accelerates significantly, and it is almost complete in 20-30 seconds at $150^{\circ} \mathrm{C}$.

The fact that the intermediate quinolinecarboxylic acids are formed at relatively low temperatures indicates that most likely the real cause for appearance of the undesirable 4-hydroxy-1,2-dihydroquinolin-2-ones as by-products in the reaction between alkyl 4-hydroxy-2-oxo-1,2-dihydroquinoline-3-carboxylate with aromatic amines is hydrolysis of the ester groups, but not their pyrolytic decomposition as previously supposed. The repetitive experiment carried out with ethyl 6-hydroxy-2-methyl-4-oxo-2,4-dihydro-1H-pyrrolo[3,2,1-ij]quinoline-5-carboxylate (1) has confirmed this conclusion. The only difference from the previous experiment is that instead of the hygroscopic DMSO- $\mathrm{d}_{6}$, toluene- $\mathrm{d}_{8}$ - the solvent with deliberately much lower water content is used. According<smiles>CCOC(=O)c1c(O)c2cccc3c2n(c1=O)C(C)C3</smiles>

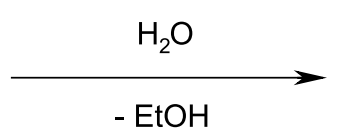<smiles>CC1Cc2cccc3c(O)c(C(=O)O)c(=O)n1c23</smiles>

1

2<smiles>[R]c1cccc(N)c1</smiles><smiles>[Y]C(=O)CC</smiles><smiles>[R]c1cccc(NC(=O)c2c(O)c3cccc4c3n(c2=O)C([Y16])C4)c1</smiles>

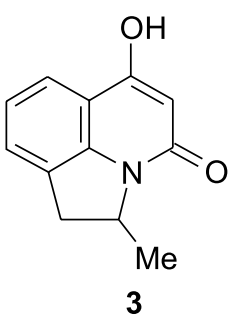

4: $\mathbf{a} \mathrm{R}=2-\mathrm{C} \equiv \mathrm{N} ; \mathbf{b} \mathrm{R}=2-\mathrm{COMe} ; \mathbf{c} \mathrm{R}=2-\mathrm{COOH} ; \mathbf{d} \mathrm{R}=3-\mathrm{COOH} ; \mathbf{e} \mathrm{R}=4-\mathrm{COOH} ; \mathbf{f} \mathrm{R}=2-\mathrm{COOMe}$; g R = 4-COOMe; $\mathbf{h} \mathrm{R}=4$-COOEt; $\mathbf{i} \mathrm{R}=4$-COOPr; $\mathbf{j} \mathrm{R}=4$-COOBu; $\mathbf{k} \mathrm{R}=2-\mathrm{CONH}_{2} ; \mathrm{I} \mathrm{R}=2$-CONHMe; $\mathbf{m} \mathrm{R}=2-\mathrm{SO}_{2} \mathrm{NH}_{2} ; \mathbf{n ~ R}=5-\mathrm{Cl}-2,4-\left(\mathrm{SO}_{2} \mathrm{NH}_{2}\right)_{2} ; \mathbf{o} \mathrm{R}=4-\mathrm{NO}_{2} ; \mathbf{p ~ R}=4-\mathrm{NH}_{2}$. 
Table 1

Physicochemical Characteristics of Anilides 4a-p

\begin{tabular}{|c|c|c|c|c|c|c|c|}
\hline \multirow{2}{*}{ Compound } & \multirow{2}{*}{$\begin{array}{l}\text { Empirical } \\
\text { formula }\end{array}$} & \multicolumn{3}{|c|}{$\frac{\text { Found, } \%}{\text { Calculated, } \%}$} & \multirow{2}{*}{$\mathrm{Mp},{ }^{\circ} \mathrm{C}$} & \multirow{2}{*}{ Yield, \% } & \multirow{2}{*}{$\begin{array}{c}\text { Diuretic } \\
\text { activity, \%** }\end{array}$} \\
\hline & & $\mathrm{C}$ & $\mathrm{H}$ & $\mathrm{N}$ & & & \\
\hline $4 a$ & $\mathrm{C}_{20} \mathrm{H}_{15} \mathrm{~N}_{3} \mathrm{O}_{3}$ & $\frac{69.44}{69.56}$ & $\frac{4.29}{4.38}$ & $\frac{12.10}{12.17}$ & $167-169$ & 78 & -4 \\
\hline $4 b$ & $\mathrm{C}_{21} \mathrm{H}_{18} \mathrm{~N}_{2} \mathrm{O}_{4}$ & $\frac{69.51}{69.60}$ & $\frac{4.88}{5.01}$ & $\frac{7.84}{7.73}$ & $158-160$ & 76 & +26 \\
\hline $4 c$ & $\mathrm{C}_{20} \mathrm{H}_{16} \mathrm{~N}_{2} \mathrm{O}_{5}$ & $\frac{66.02}{65.93}$ & $\frac{4.55}{4.43}$ & $\frac{7.62}{7.69}$ & $232-234$ & 80 & +152 \\
\hline $4 d$ & $\mathrm{C}_{20} \mathrm{H}_{16} \mathrm{~N}_{2} \mathrm{O}_{5}$ & $\frac{66.01}{65.93}$ & $\frac{4.50}{4.43}$ & $\frac{7.74}{7.69}$ & $255-257$ & 85 & +95 \\
\hline $4 e$ & $\mathrm{C}_{20} \mathrm{H}_{16} \mathrm{~N}_{2} \mathrm{O}_{5}$ & $\frac{65.85}{65.93}$ & $\frac{4.36}{4.43}$ & $\frac{7.60}{7.69}$ & $281-283$ & 88 & +110 \\
\hline $4 f$ & $\mathrm{C}_{21} \mathrm{H}_{18} \mathrm{~N}_{2} \mathrm{O}_{5}$ & $\frac{66.79}{66.66}$ & $\frac{4.88}{4.79}$ & $\frac{9.32}{7.40}$ & $188-190^{*}$ & 79 & -1 \\
\hline $4 g$ & $\mathrm{C}_{21} \mathrm{H}_{18} \mathrm{~N}_{2} \mathrm{O}_{5}$ & $\frac{66.75}{66.66}$ & $\frac{4.86}{4.79}$ & $\frac{7.49}{7.40}$ & 187-199* & 87 & +110 \\
\hline $4 \mathrm{~h}$ & $\mathrm{C}_{22} \mathrm{H}_{20} \mathrm{~N}_{2} \mathrm{O}_{5}$ & $\frac{67.23}{67.34}$ & $\frac{5.02}{5.14}$ & $\frac{7.01}{7.14}$ & $176-178^{*}$ & 90 & +67 \\
\hline $4 i$ & $\mathrm{C}_{23} \mathrm{H}_{22} \mathrm{~N}_{2} \mathrm{O}_{5}$ & $\frac{68.08}{67.97}$ & $\frac{5.54}{5.46}$ & $\frac{6.80}{6.89}$ & $134-136^{*}$ & 89 & -10 \\
\hline $4 j$ & $\mathrm{C}_{24} \mathrm{H}_{24} \mathrm{~N}_{2} \mathrm{O}_{5}$ & $\frac{68.65}{68.56}$ & $\frac{5.83}{5.75}$ & $\frac{6.54}{6.66}$ & $125-127^{*}$ & 83 & +27 \\
\hline $4 k$ & $\mathrm{C}_{20} \mathrm{H}_{17} \mathrm{~N}_{3} \mathrm{O}_{4}$ & $\frac{66.22}{66.11}$ & $\frac{4.84}{4.72}$ & $\frac{11.47}{11.56}$ & $259-261$ & 77 & +3 \\
\hline 41 & $\mathrm{C}_{21} \mathrm{H}_{19} \mathrm{~N}_{3} \mathrm{O}_{4}$ & $\frac{66.74}{66.83}$ & $\frac{4.95}{5.07}$ & $\frac{11.02}{11.13}$ & 203-205 & 75 & +37 \\
\hline $4 m$ & $\mathrm{C}_{19} \mathrm{H}_{17} \mathrm{~N}_{3} \mathrm{O}_{5} \mathrm{~S}$ & $\frac{57.00}{57.13}$ & $\frac{4.17}{4.29}$ & $\frac{10.44}{10.52}$ & $227-229$ & 78 & +14 \\
\hline $4 n$ & $\mathrm{C}_{19} \mathrm{H}_{17} \mathrm{CIN}_{4} \mathrm{O}_{7} \mathrm{~S}_{2}$ & $\frac{44.38}{44.49}$ & $\frac{3.26}{3.34}$ & $\frac{11.03}{10.92}$ & $315-317$ & 72 & +17 \\
\hline 40 & $\mathrm{C}_{19} \mathrm{H}_{15} \mathrm{~N}_{3} \mathrm{O}_{5}$ & $\frac{62.58}{62.46}$ & $\frac{4.23}{4.14}$ & $\frac{11.42}{11.50}$ & $231-233$ & 85 & +20 \\
\hline $4 p$ & $\mathrm{C}_{19} \mathrm{H}_{17} \mathrm{~N}_{3} \mathrm{O}_{3}$ & $\frac{67.94}{68.05}$ & $\frac{4.98}{5.11}$ & $\frac{12.65}{12.53}$ & $210-212$ & 91 & +5 \\
\hline & Hydrochlorothiazide & & & & & & +53 \\
\hline
\end{tabular}

* Recrystallized from ethyl acetate, the remaining material is the mixture of DMF and ethanol.

$* * \ll+\gg$ Indicates increase and «-» inhibition of diuresis when compared with the control taken as $100 \%$.

to the ${ }^{1} \mathrm{H}$ NMR spectral data boiling of tricyclic ester 1 in toluene- $d_{8}\left(\sim 110^{\circ} \mathrm{C}\right)$ for 10 minutes does not cause any significant changes in its structure. But after adding $\mathrm{D}_{2} \mathrm{O}$ to the test solution decomposition of the initial ester 1 to 6-hydroxy-2-methyl-4-oxo-2,4dihydro- $1 H$-pyrrolo[3,2,1-ij]quinolin-4-ones (3) has been observed by approximately $50 \%$ after boiling for 3 minutes (Scheme).

It becomes clear from this study that at the temperature of $95^{\circ} \mathrm{C}$ and higher the sensitivity of 4-hydroxy-2-oxo-1,2-dihydroquinoline-3-carboxylic acids esters in solution or a melt to hydrolysis increases significantly. Therefore, if the synthesis of $\mathrm{N}$-substituted amides based on them requires such severe 18 conditions, water should be removed from the reagents and solvents in order to avoid contamination of the final products with 4-hydroxy-1,2-dihydroquinolin-2-ones. This fact is of particular relevance while working with amines of the low reactivity when hydrolysis can be a significant competitive process for amidation or even become the main direction of the reaction.

Practically, it is sufficient to dry 4-hydroxy-2-oxo1,2-dihydroquinoline-3-carboxylic acids esters to the constant weight at $50^{\circ} \mathrm{C}$ before amidation. Sometimes it must be done in a vacuum desiccator over $\mathrm{P}_{2} \mathrm{O}_{5}$, because some of them might form crystal hydrates [12]. Water is removed from amines by various con- 


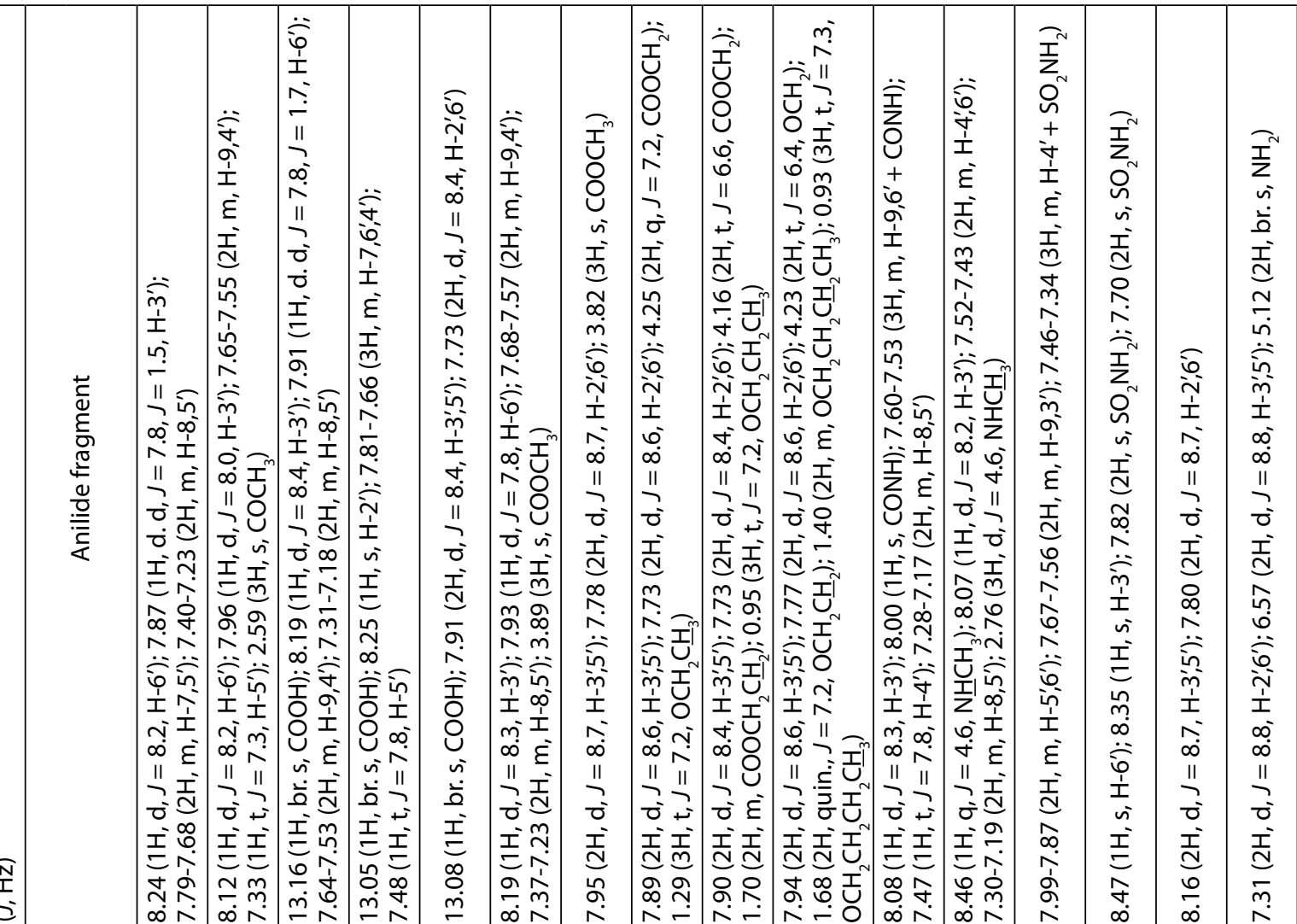

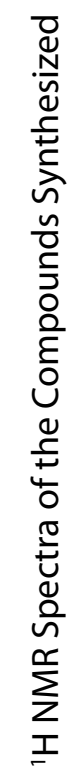

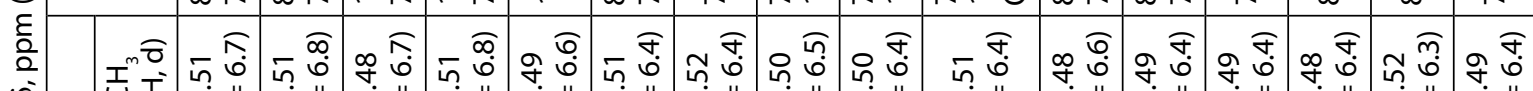

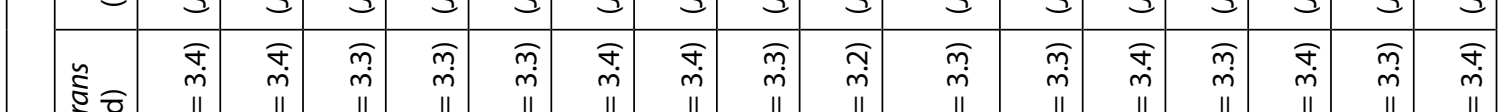

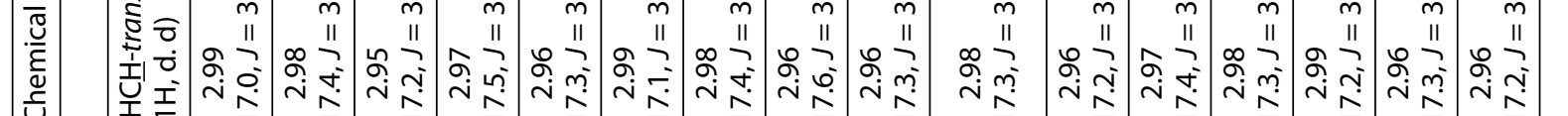
ᄋ̆

.

ํㅡㅇ

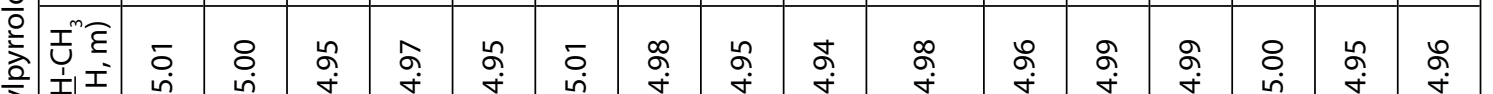

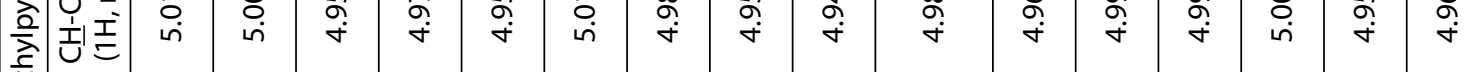

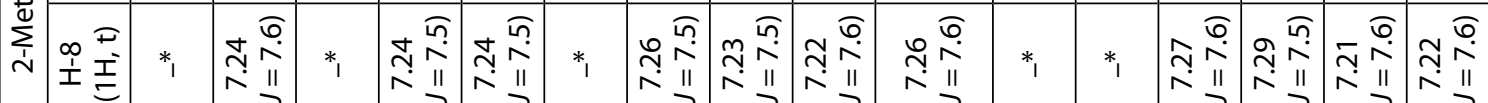

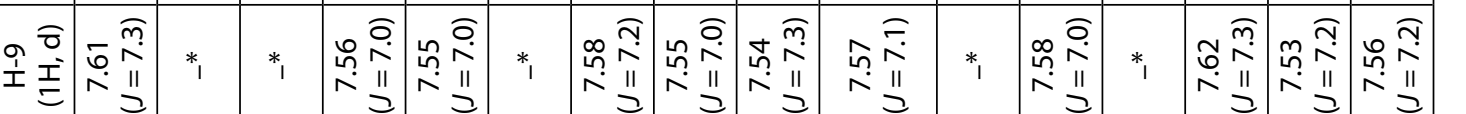

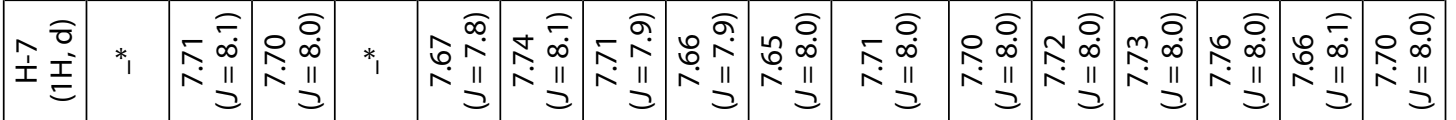

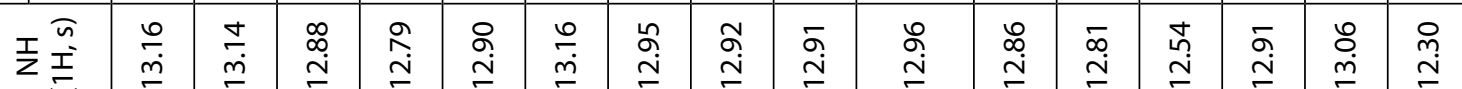

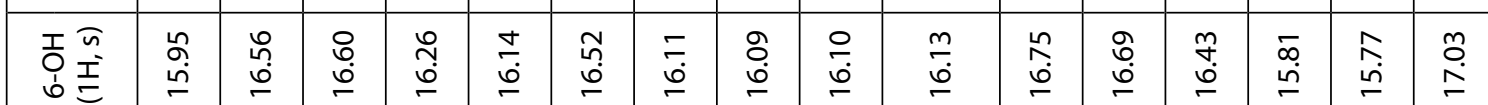

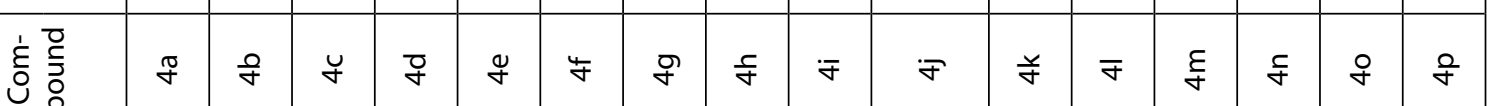


ventional methods depending on their structures and physical conditions. According to our observations xylenes (or their mixtures), and bromobenzene are the most suitable solvents: they are stable, have a good solvent ability, have relatively high boiling points, can be easily dried and regenerated.

According to these easy-to-implement recommendations we have obtained a series of new $\mathrm{N}$-aryl-6hydroxy-2-methyl-4-oxo-2,4-dihydro- $1 \mathrm{H}$-pyrrolo [3,2,1-ij]quinoline-5-carboxamides 4a-p with electron-accepting substituents in the anilide fragment of the molecule (Table 1 and Table 2) with good yields. 4-Amino derivative $4 p$ in this series, of course, is not included, but to identify its structural and biological regularities we decided to consider it together with 4-nitroanilide 4o. In the ${ }^{1} \mathrm{H}$ NMR spectra of the crude anilides 4a-p obtained in compliance with the conditions offered the impurity of pyrrolo[3,2,1-ij] quinolin-4-ones 3 has not been detected. Therefore, if the undesirable hydrolysis of ester $\mathbf{1}$ takes place, it is very insignificant. For comparison, an attempt to use the commercial anthranilonitrile (i.e. the one which does not require additional drying) in the synthesis while all the other conditions were equal led to formation of a mixture of the target 2-cyananilide $\mathbf{4 a}$ and pyrrolo[3,2,1-ij]quinolin-4-one $\mathbf{3}$ in the ratio of $\sim 2: 3$ according to the ${ }^{1} \mathrm{H}$ NMR spectral data.

The screening of the diuretic properties of all anilides 4a-p synthesized was conducted in white rats weighing 180-200 g according to the standard method [13]. The compounds tested were introduced orally in a fine aqueous suspension stabilized with Tween80 . The dose was $10 \mathrm{mg} / \mathrm{kg}$. One of the most famous diuretic - Hydrochlorothiazide [14] in its effective dose of $40 \mathrm{mg} / \mathrm{kg}$ was used as a reference drug.

The analysis of the results of biological screening given in Table 1 shows that $\mathrm{N}$-acyl derivatives of amino-benzoic acid 4c-e deserve special attention among all the tested compounds. Though their dose is much lower, their diuretic activity is 2-3 times higher than that of the reference drug. Moreover, there is a well-defined relationship between the level of their diuretic effect and the position of the carboxyl group in the anilide ring: $2>4>3$. The transformation of acids $\mathbf{4 c}, \mathbf{e}$ to their esters has a mixed influence on their biological properties. For example, the activity of para-substituted methylbenzoate $\mathbf{4 g}$ remains at the same level as of its acid $\mathbf{4 e}$, while its closest homologues $\mathbf{4 h} \mathbf{h} \mathbf{j}$ lose the ability to increase urine output up to appearance of the antidiuretic properties of propyl ester 4i. Modification of 2-carboxyl group is more categorical: its esterification (methyl ester $\mathbf{4 f}$ ) and amidation (amides $\mathbf{4 k}, \mathbf{l}$ ) should be considered as unreasonable. Despite the expectations, sulphonamides $\mathbf{4 m}, \mathbf{n}$ were not active either. In comparison with the previously studied unsubstituted phenylamide of 6-hydroxy-2-methyl-4-oxo-2,4-dihydro-1H-pyrrolo[3,2,1-ij]quinoline-5-carboxylic acid [9], nitro- and amine groups in the para-position of the anilide ring (amides 4o,p) contribute to appearance of diuretic properties, but in general, their positive impact is insignificant.

\section{Experimental Part}

The ${ }^{1} \mathrm{H}$ NMR spectra of the anilides $4 \mathbf{4 a - p}$ synthesized were recorded on a Varian Mercury-400 spectrometer $\left(400 \mathrm{MHz}\right.$ ) in DMSO- $\mathrm{d}_{6}$. Investigation of stability of esters of quinoline-3-carboxylic acids to hydrolysis was carried out with the help of the same device, the solvent was DMSO- $\mathrm{d}_{6}$ or toluene- $\mathrm{d}_{8}$. TMS served as the internal standard in all cases. Ethyl ester of 6-hydroxy-2-methyl-4-oxo-2,4-dihydro- $1 H$ pyrrolo[3,2,1-ij]quinoline-5-carboxylic acid (1) was obtained according to our previous procedure [9].

6-Hydroxy-2-methyl-4-oxo-2,4-dihydro-1H-pyrrolo[3,2,1-ij]quinoline-5-carboxylic Acid Anilides 4a-p (General Method). Mix a pre-dried mixture of $2.73 \mathrm{~g}(0.01 \mathrm{~mol})$ of ethyl ester 1, the corresponding aniline $(0.01 \mathrm{~mol})$ and $2 \mathrm{ml}$ of xylene and allow to stand on a metal bath at $130^{\circ} \mathrm{C}$ for $20-30$ minutes. Cool the reaction mixture, add $10 \mathrm{ml}$ of ethanol and triturate thoroughly. Filter the precipitated anilide 4a-p, wash with alcohol, dry, and recrystallize from the suitable solvent (see Table 1).

\section{References}

1. Ukrainets I.V., Gorokhova O.V., Andreeva X.V., Sim G. // Int. J. Pharm. Pharmacol. - 2012. - Vol. 1, №3. P. 33-40.

2. Jönsson S., Andersson G., Fex T. et al. // J. Med. Chem. - 2004. - Vol. 47, №8. - P. 2075-2088.

3. Collin X., Robert J.M., Duflos M. et al. //J. Pharm. Pharmacol. - 2001. - Vol. 53, №3. - P. 417-423.

4. Khan S.R., Mhaka A., Pili R., Isaacs J.T. // Bioorg. Med. Chem. Lett. - 2001. - Vol. 11, №4. - P. 451-452.

5. Björk A., Jönsson S., Fex T., Hedlund G. / US Patent 6077851. - 2000.

6. Kutyrev A., Kappe T. // J. Heterocyclic Chem. - 1997. - Vol. 34, №5. - P. 969-972.

7. Ukrainets I.V., Kolesnik E.V., Sidorenko L.V. et al. // Chem. Heterocycl. Comp. - 2006. - Vol. 42, №6. P. 765-775.

8. Ukrainets I.V., Mospanova E.V., Sidorenko L.V.//Chem. Heterocycl. Comp. - 2007. - Vol. 43, №7. - P. 863-870.

9. Ukrainets I.V., Golik N.Yu., Shemchuk A.L. et al. //Chem. Heterocycl. Comp. - 2011. - Vol. 47, №7. - P. 826-832. 
10. Ukrainets I.V., Bevz O.V., Mospanova E.V. et al. //Chem. Heterocycl. Comp. - 2012. - Vol. 48, №2. - P. 320-326.

11. Ukrainets I.V., Davidenko A.A., Mospanova E.V. et al. // Chem. Heterocycl. Comp. - 2010. - Vol. 46, №5. P. 559-568.

12. Ukrainets I.V., Gorokhova O.V., Sidorenko L.V. et al. // Zh. Org. Farm. Khim. - 2005. - Vol. 3, Is. 3 (11). P. 20-25.

13. Sernov L.N., Gatsura V.V. Elements of Experimental Pharmacology [in Russian]. - Moscow: Nauka, 2000. P. 103-104.

14. Mashkovskii M.D. Drugs [in Russian]. - Moscow: RIA Novaya Volna - Izd. Umerenkov, 2009. - P. 499-500.

Надійшла до редакції 23.03.2013 p. 